\title{
Karst flash floods: an example from the Dinaric karst (Croatia)
}

\author{
O. Bonacci ${ }^{1}$, I. Ljubenkov ${ }^{2}$, and T. Roje-Bonacci ${ }^{1}$ \\ ${ }^{1}$ Faculty of Civil Engineering and Architecture, Univ. of Split, Matice Hrvatske str. 15, 21000 Split, Croatia \\ ${ }^{2}$ Faculty of Civil Engineering and Architecture, Univ. of Split, Matice Vukovarska 35, 21000 Split, Croatia
}

Received: 13 September 2005 - Revised: 15 February 2006 - Accepted: 16 February 2006 - Published: 31 March 2006

\begin{abstract}
Flash floods constitute one of the deadliest and costliest natural disasters worldwide. This paper explains the karst flash flood phenomenon, which represents a special kind of flash flood. As the majority of flash floods karst flash floods are caused by intensive short-term precipitation in an area whose surface rarely exceeds a few square kilometres. The characteristics of all flash floods are their short duration, small areal extent, high flood peaks and rapid flows, and heavy loss of life and property. Karst flash floods have specific characteristics due to special conditions for water circulation, which exist in karst terrains. During karst flash floods a sudden rise of groundwater levels occurs, which causes the appearance of numerous, unexpected, abundant and temporary karst springs. This paper presents in detail an example of a karst flash flood in the Marina bay (Dinaric karst region of Croatia), which occurred in December 2004.
\end{abstract}

\section{Introduction}

During the last few decades flash floods have constituted one of the deadliest and costliest natural disasters which can occur almost everywhere in the world. In recent times, great attention has been devoted to flash floods, prompted by many catastrophic events occurring all over the world.

Flash floods are one of the most impressive hazardous manifestations of the environment which directly affects human activity and security and whose origins and developments are not yet well enough understood and controlled by humankind. There are many ways to prevent flash floods but no matter how well any one method works its effect is always limited (Lin, 1999).

The objective of this paper is to describe in detail and explain the existence of one special kind of flash flood called

Correspondence to: O. Bonacci

(obonacci@gradst.hr) the karst flash flood. Water circulation in karst areas is different than in non-karst areas, which is the main reason for the strongly different characteristics of karst and non-karst flash floods.

This paper presents in detail an example of karst flash flood which occurred in December 2004 in Marina bay located in a deep and bare Dinaric karst near the Adriatic Sea coast of Croatia.

\section{Flash flood characteristics}

Flash floods are often the result of convectional storms or of high-intensity rain cells associated with frontal storms. These storms drop large amounts of rain within a brief period, often measured in minutes rather than hours. Flash floods may be also caused or intensified by rapid snow melting. It may indicate that a storm has occurred on a steep, bare, impermeable surface such as a narrow mountain valley or a heavily built-up urban area, or in a small catchment through which the resulting flood peak passes too rapidly for adequate flood warnings to be given (Smith and Ward, 1998). Steep terrain, excessive antecedent precipitation and thin, bare and/or impermeable soil or cover conspire to create conditions highly conductive to flash flooding.

Overland flow tends to play the dominant role in flash flood formation. Low infiltration capacity is the most important factor for overland flow development, which results from physical, chemical and biological factors (Smith and Ward, 1998).

These factors' sudden appearance and disappearance in headwater streams led to the term "flash flood" (Ward, 1978). Flash floods occur with little or no warning and can reach their full peak in only a few minutes. Flash flood hydrographs have sharp peaks. Their rising and falling limbs are very steep with an almost equal duration. Because of the short-lived and destructive nature of flash floods, their

Published by Copernicus GmbH on behalf of the European Geosciences Union. 
discharge measurements are extremely complex very often remain an unsolved task. The specific peak discharge of flash floods is greater than 10 and can reach a value of $100 \mathrm{~m}^{3} \mathrm{~s}^{-1} \mathrm{~km}^{-2}$.

Flash flood waters move at very fast speeds and can kill people, roll boulders, tear out trees, destroy buildings, obliterate bridges and increase the potential for landslides and mudslides. Archer (1992) called flash floods walls of water. They can reach heights of 3 to $6 \mathrm{~m}$ and generally are accompanied by deadly cargo debris. While the flash floods peak discharges are much higher than for normal floods, the total hydrograph volumes of flash floods are quite small. Due to this reason the flash flood volume is not necessarily important.

Flash floods are often discussed especially in the context of arid and semi-arid environments. To an even greater extent than in humid regions, floods in arid and semi-arid areas are generated on only a small fraction of a drainage basin. This partly reflects the way in which overland flow, generated on smooth or steeply sloping ground surfaces having sparse vegetation cover, may deliver sudden-onset flood flows and result in rapidly rising hydrographs (Smith and Ward, 1998). Cohen and Laronne (2005) state that suspended sediment transported by flash floods in deserts is much higher than what is typical of perennial fluvial humid environments. The sediment yield of individual events is large, but the small number of floods limits the mean annual sediment yield to low values in these arid environments.

The suddenness and unexpectedness accompanied by catastrophic consequences are the main characteristic of all flash flooding. The prediction and forecasting of flash floods is an extremely difficult and unreliable issue (Hall, 1981; Lin, 1999). The key feature of flash flood forecasting is to identify quickly when the forecast flood is above the threshold rather than the exact peak discharge and time of occurrence. Hence, flash flood forecasting does not require a complex model. The US National Weather Service identified a need for improving flash flood guidance procedures. Carpenter et al. (1999) describe a procedure developed to provide improved estimates of threshold runoff. Threshold runoff has been defined as the amount of rainfall excess of a given duration necessary to cause flooding on small streams.

For practical and operational reasons Lin (1999) distinguishes natural from artificial flash floods. Artificial flash floods have nothing to do with abnormal climatic changes, except in some very specific cases. They are caused by structural failures. For example, dam-break flash floods arise when a storm occurs with a magnitude over and above the design limits on the structure or because of a failure in dam construction. In this case their kinetic energy is great and transport capacity is strong.

\section{Karst, karst aquifer, water circulation in karst and catchment in karst}

Karst is defined as a terrain, generally underlain by limestone or dolomite, in which the topography is chiefly formed by the dissolving of rock, and which may be characterised by sinkholes, sinking streams, closed depressions, subterranean drainage and caves. A wide range of closed surface depressions, a well-developed underground drainage system, and a strong interaction between the circulation of surface water and groundwater typify karst areas. It represents terrain with distinctive hydrogeology, hydrology and landforms arising from a combination of high solubility and well-developed secondary porosity. Due to very fast infiltration rates, especially in bare Dinaric karst, overland flow and the existence of permanent open streamflows in karst terrains are rare (Bonacci, 1987).

Trudgill (1985) states that while the general functions of fluvial systems in karst and non-karst areas may be similar, their geomorphological effects are different. Karst landforms can be seen in the context of a fluvial system. Vertically oriented karst features collect and transport very fast water from the surface to the underground fluvial system.

The water recharged into karst aquifers moves downgradient through them using a combination of highly anisotropic pathways. Karst aquifers are a triple porosity system consisting of: 1) Matrix permeability; 2) Fracture permeability; 3) Conduit permeability. Matrix permeability is a complex of voids in a small rock fragment with a volume of about 10 to $100 \mathrm{~cm}^{3}$. The matrix consists of not only intergranular pores but also micro fissures, and small karst voids (Choquette and Pray, 1970; Motyka, 1998). Fracture permeability is formed from mechanical joints, joint swarms and bedding plane partings, mainly enlarged by solution. Conduit permeability is represented by pipe-like openings with apertures ranging from $1 \mathrm{~cm}$ to a few tens of meters (White, 2002). The average values of the effective porosity of karst massif generally vary from 0.1 to $1 \%$.

Karst aquifers have complex and original characteristics which make them very different from other aquifers: high heterogeneity created and organised by groundwater flow, large voids, high flow velocities and high flow rate springs (Bakalowicz, 2005). The most important features of karst aquifers are the conduits which provide low resistance pathways for groundwater flow. White (2002) states that conduit flow often has more in common with surface water than groundwater. For him karst hydrology requires a mix of surface water concepts and groundwater concepts. Karst aquifers are generally continuous. However, numerous subsurface morphologic features (caves, chasms, conduits, fractures, impermeable layers, etc.) strongly influence the continuity of the aquifer, and commonly the aquifer does not function as a continuum in a catchment (Bonacci, 2001).

Karst aquifers with a high degree of integrated conduit permeability transmit water on a time scale that is short with 


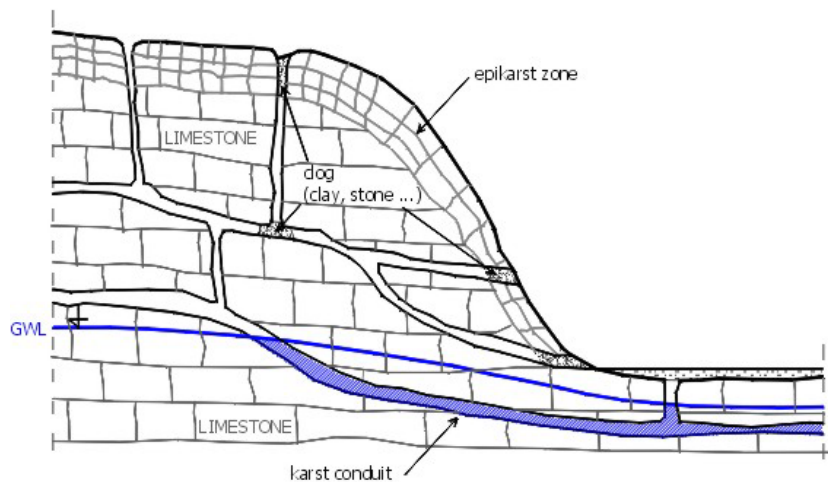

Fig. 1. Schematic presentation of the zero-state of karst system before a karst flash flood and after the long lasting dry period.

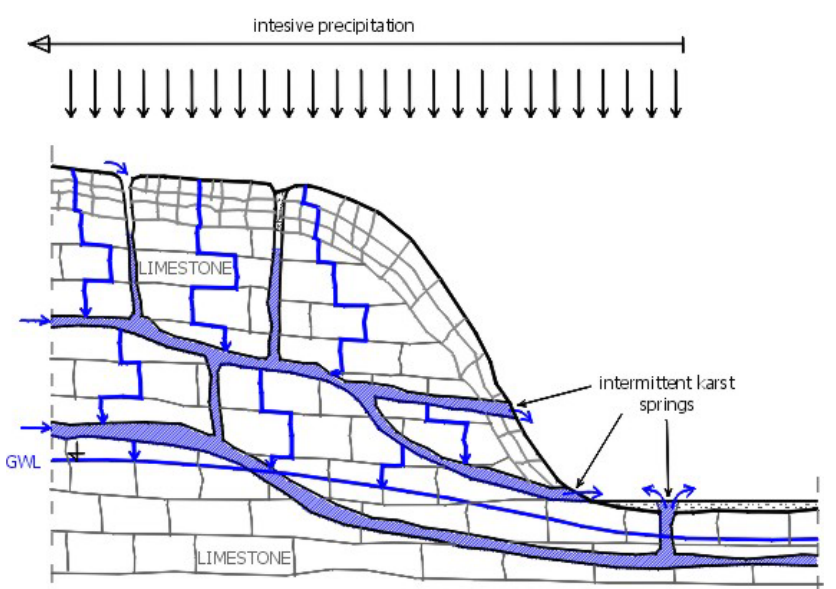

Fig. 2. Schematic presentation of karst system during the flash flood in moment when karst conduits are full with water, and when groundwater level is not start to rise.

respect to the time required for chemical reactions between water and the limestone bedrock to reach equilibrium. As a result, the chemistry of the water fluctuates rapidly during the passage of storm inputs (Hess and White, 1988).

Water circulation over and throughout a karst terrain significantly differs from that in other types of terrain, primarily due to rapid rates of infiltration and the influence of the solutionally enlarged underground aquifer, clearly distinguishing it from porous aquifers and other types of fracture aquifers (Bonacci, 2004). In karst aquifers water is being collected in networks of interconnected cracks, joints, caverns and conduits.

The hydraulic permeability of karst aquifers is essentially created by flowing water and has an anisotropic character. One of the most important characteristics of karst aquifers is the high degree of heterogeneity in their hydraulic properties. Due to the complexity of the karst medium, many experts think that every karst aquifer should be considered as being representative of itself. This is only the partial truth.

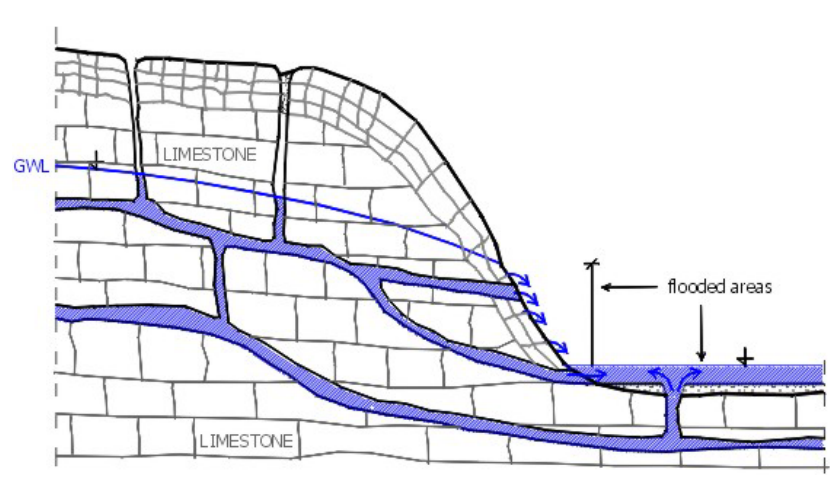

Fig. 3. Schematic presentation of karst system during the karst flash flood when groundwater level in karst aquifer is in its maximum.

Fortunately, common characteristics in karst aquifer structure and in groundwater flow allow their analysis, modelling and exploitation.

The direct exposure of karst terrains facilitates the initiation of karst drainage, and its later evolution through sinkholes at the main points of water infiltration (Ford and Williams, 1989). Scale issues are particularly important for understanding and modelling karst water circulation. Conditions in a karstified medium are strongly dependent on space and time scales, especially in a deep and morphologically complex vadose zone. This zone with a karst aquifer form a two-component system in which the major part of storage is in the form of true groundwater in narrow fissures, where diffuse or laminar flow prevails. On the other hand, the majority of water is transmitted through the karst underground by quick or turbulent flows in solutionally enlarged conduits. Conduit and matrix flow occur both in vadose and phreatic zones. Kiraly (1994) explains the concept of "karst duality" as a direct consequence of karst's extremely heterogenic structure. Duality exists in: infiltration processes, the groundwater flow field, and discharge conditions. The minimum diameter of karst conduits in which turbulent flow could exist should be greater than 5 to $15 \mathrm{~mm}$ (Ford and Ewers, 1978). Interaction between the two above mentioned types of flow is significant and permanently present.

In karst terrains catchment boundaries and areas are fragmentally unknown. The catchment area in karst defined from surface morphology (i.e. topographic catchment) rarely corresponds to the karst hydrological or hydrogeological drainage basin. The differences between the topographic and hydrological catchments in karst terrain are, as a rule, so large that data about the topographic catchment are useless in practice. This fact causes a lot of difficulty in karst flash flood forecasting and controlling.

The position of the watershed limit depends upon the groundwater level, which can change very quickly, especially after high-intensity precipitation which may cause flash flooding. Generally at very high groundwater levels fossil and inactive conduits and springs are activated, 


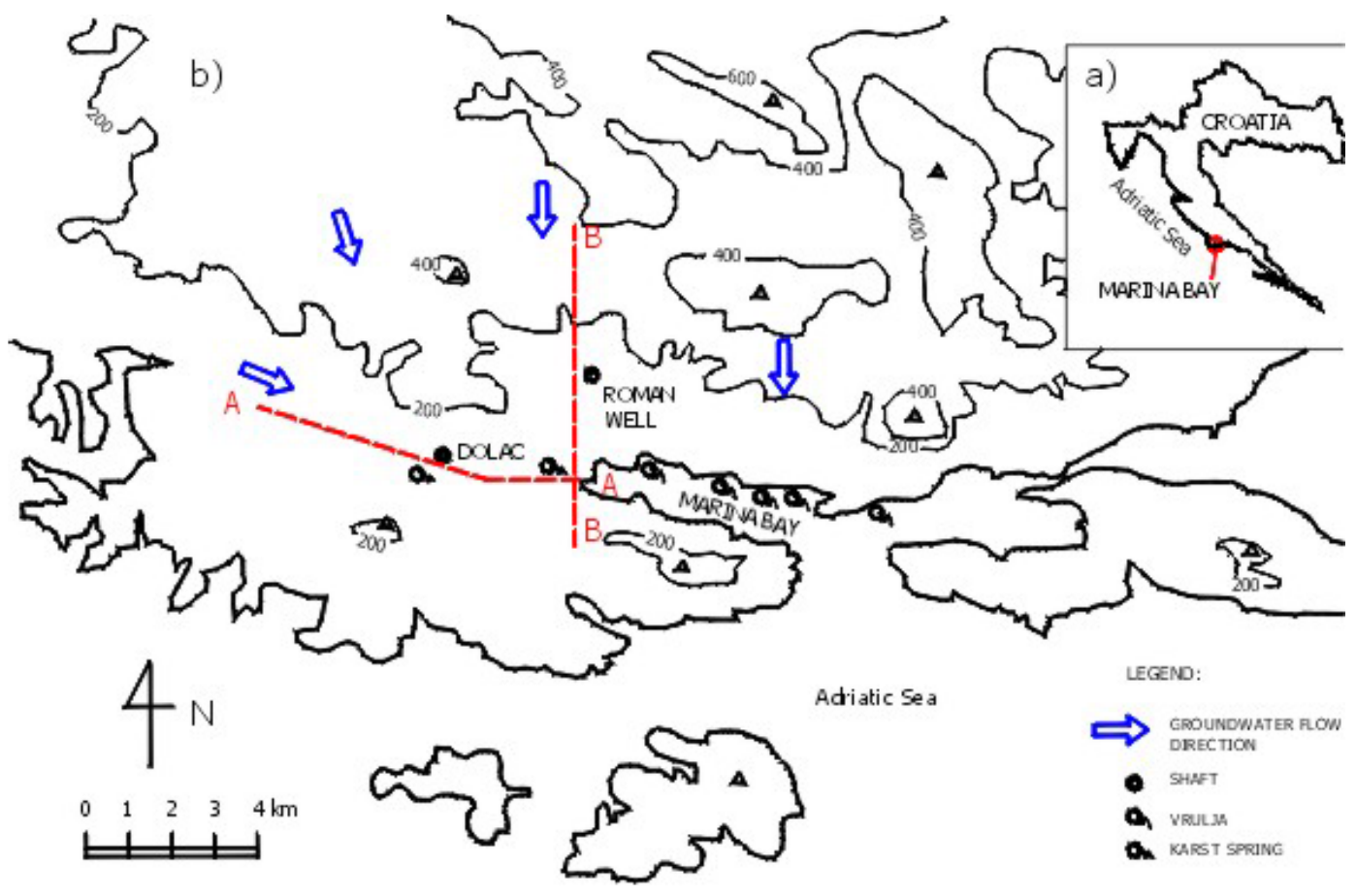

Fig. 4. (a) Map of study area; (b) Topographic location map indicating shafts, groundwater flow directions, karst springs and submarine karst springs.

which cause intercatchment overflow and the redistribution of catchment areas (Bonacci, 1995). For understanding the karst system it is crucial to explain the interaction of groundwater and surface water. This is of special importance for karst flash floods analysis.

\section{Karst flash flood characteristics}

The previously established facts about flash flooding and water circulation in karst areas clearly indicate that the characteristics of flash flooding in karst terrains should be strongly and definitely different than in non-karst terrains. Karst flash floods have specific characteristics caused by distinct conditions for water circulation and storage over and in a karstified medium.

The root causes of karst-flash-flood-specific characteristics are: 1) High infiltration rate; 2) Rare or non existence of overland flow and open streams; 3 ) Strong interaction between the circulation of surface water and groundwater in karst areas; 4) Small storage capacity of the karst medium; 5) Fast groundwater flow through karst conduits; 6) Strong and direct connections between surface inflow through different kinds of swallow-holes (ponors) and outflow through permanent and intermittent karst springs; 7) Existence of many unknown underground and surface karst features such as caves, jamas, conduits, sinkholes, karrens etc.; 8) High and fast oscillations of groundwater levels in karst areas (Jourde et al., 2005); 9) Interbasin overflow and/or redistribution of the catchment areas caused by groundwater rising; 9) Limited discharge capacity of many karst springs (Bonacci, 2001); 10) Limited capacity of swallow-holes (Bonacci, 1987).

A special case of flash flooding was the catastrophic flooding of the town of Cetinje and the Cetinje karst polje (Serbia and Montenegro) in February 1986. This catastrophic karst flash flood is an example of the unfortunate coincidence of environmental extremes (extremely intensive precipitation and fast snow melting), the limited swallow capacity of ponors and ineffective human intervention in the karst massif by the cutting of an artificial tunnel (Bošković and Živaljević, 1986; Mijatović, 1987; Bonacci and Živaljević, 1993; Bonacci, 2004).

For karst flash floods the volume of the hydrograph is much more important than in cases of non-karst flash floods. Due to very fast infiltration rates, overland flow and the existence of open watercourses on karst terrains are rare. Practically all rainfall quickly penetrates the karst underground where it fills karst voids of different dimensions, and at the same time flows under the influence of gravity. As the capacity of karst voids is not large, groundwater level rising is very fast. This is especially manifested during short-term intensive precipitation. In this time the system of karst conduits becomes pressurized. In the Dinaric karst the intensity of groundwater level rise can exceed a value of $30 \mathrm{~m} \mathrm{~h}^{-1}$ (Bonacci, 1987, 1995).

Because of the previously mentioned reasons fossil and inactive karst conduits and springs are activated, and 
groundwater breakthrough on the surface occurs in many unexpected places. The unexpected and rushed occurrence of many abundant intermittent karst springs is one of the main characteristics of karst flash flooding. One consequence of this is that generally it is not possible to measure discharges during karst flash floods. This represents one of the greatest obstacles, which makes it impossible for understanding karst flash flood phenomena and its modelling and controlling.

An attempt to present schematically three phases of karst flash flood development is given in Figs. 1, 2 and 3. Figure 1 shows the so-called zero state, i.e. the situation of a karst system immediately before the start of intensive rain, and after a long dry period; the groundwater level is low, the water table is below the lowest terrain, and the groundwater does not flow through the karst conduits. Some of the karst conduits are clogged by clay or stones, and in the analysed area there are no functioning karst springs.

Figure 2 shows the situation immediately after the beginning of intensive precipitation. The groundwater level is still at the same position as during the zero state but the existing karst conduits are full with water. The flow within is under pressure and the groundwater in the karst conduits is very high. Due to groundwater pressure some of the clogs in the conduits are removed and intermittent springs occurred on the slopes and in the lowlands. If the intensity and quantity of precipitation are large enough, overland flow on some parts of the terrain can occur. Due to this manifestation of factors the flash flood started. The duration of this phase was not long: it lasted from ten minutes to a few hours (Bonacci, 1995). During this time large and well connected karst conduits, in which fast turbulent flows existed, were filled. The flow under pressure was formed only in the karst conduits, whereas small tectonic and karst fissures, which form matrix and intergranular permeability, were not yet filled by groundwater.

Small karst fissures started to fill by a slow laminar or transitional flow regime (Atkinson, 1977). It should be noted that maximum groundwater level amplitude in deep and bare Dinaric karst can reach more than 120 m (Bonacci, 1987; Bonacci and Roje-Bonacci, 2000). The epikarst zone filled with a huge quantity of water.

Figure 3 shows the next phase of the same karst flash flood when groundwater in a karst aquifer reached its maximum value. This groundwater level is lower than in the phase showed in Fig. 2 where the groundwater level rose only in karst conduits. In the Dinaric karst this difference can be considerable, more than a few tens of meters. Very often the consequences of karst flash floods are landslides and mudslides. The phase showed in Fig. 3 lasted longer than the phase showed in the preceding Fig. 2, and their duration depends on local hydrological, geomorphological and hydrogeological characteristics. The duration of any floods in karst areas strongly depends on the capacity of natural and artificial evacuation organs, especially swallow-holes.

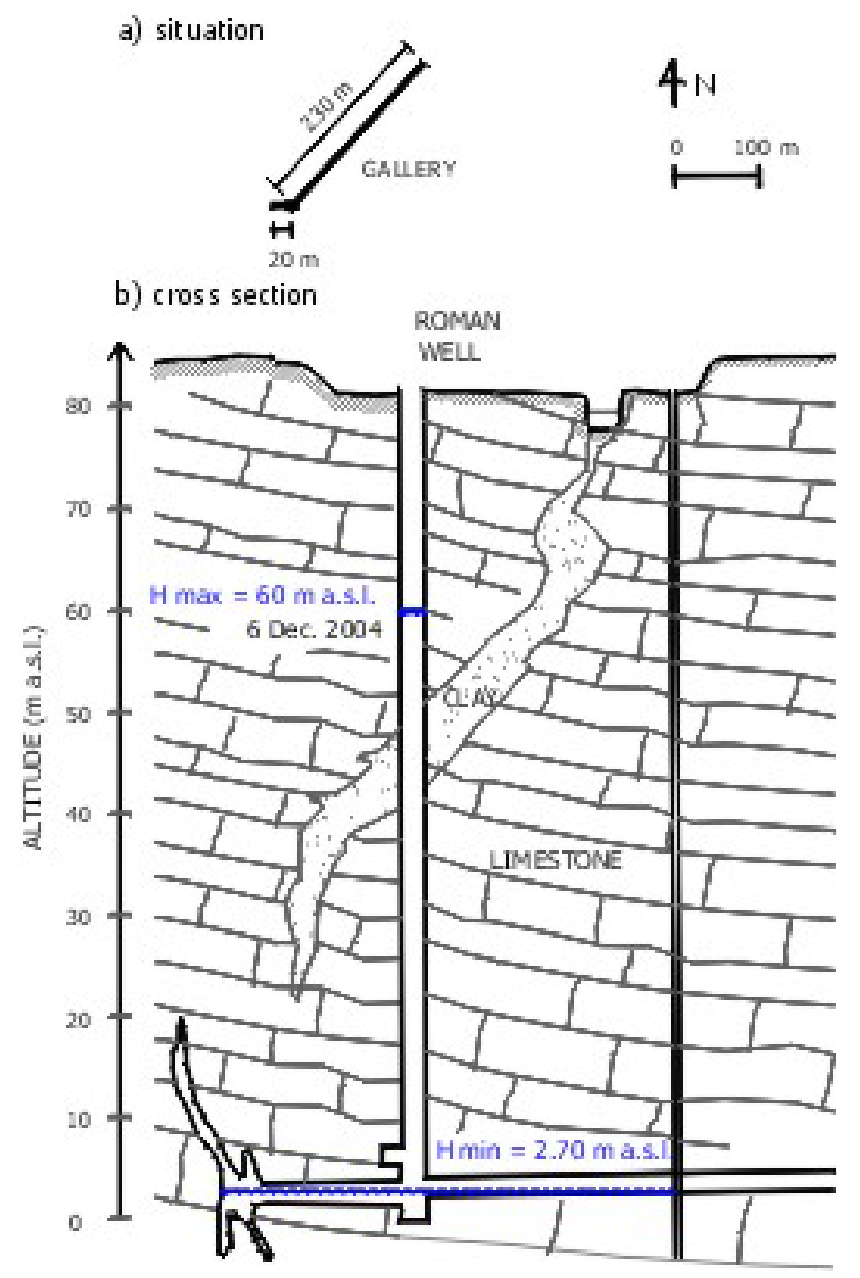

Fig. 5. (a) Situation of the Roman well gallery; (b) Cross-section through the Roman well shaft indicating minimum and maximum measured groundwater level.

\section{The karst flash flood in December 2004}

On 6 December 2004 a strong karst flash flood affected Marina bay and the village of Marina situated on the central part of the Croatian Adriatic Sea coast, which belongs to the central part of the bare and deep Dinaric karst region. Figure $4 \mathrm{a}$ contains a map of Croatia showing the position of the studied area. Figure 4b shows a detailed topographic map of Marina bay indicating the positions of two water supply shafts (Roman well and Dolac), groundwater flow directions, permanent karst springs, submarine karst springs (vruljas) and two cross-sections (A-A and B-B).

The area under study consists of Cretaceous and Eocene material consisting of mostly limestone and only partially of dolomites (Roje-Bonacci et al., 2000). Their infiltration coefficient is practically endless. Due to this reason in larger areas there do not exist the conditions for the formation of neither permanent nor intermittent open water courses 


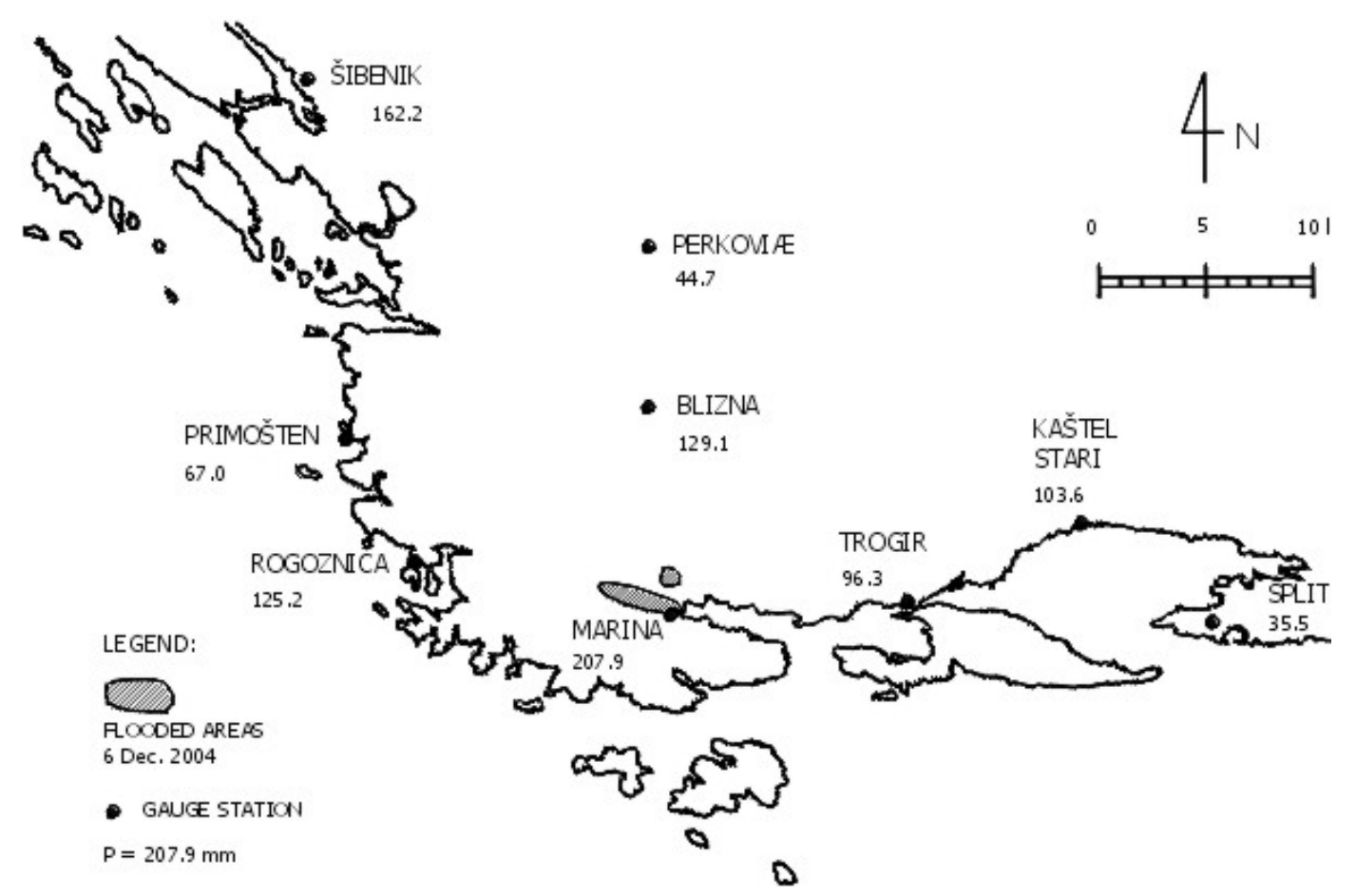

Fig. 6. Study area location map indicating position of nine rain gauging stations and precipitation felt from $7 \mathrm{~h}$ on $5 \mathrm{December} 2005$ to $7 \mathrm{~h}$ on 6 December 2005.

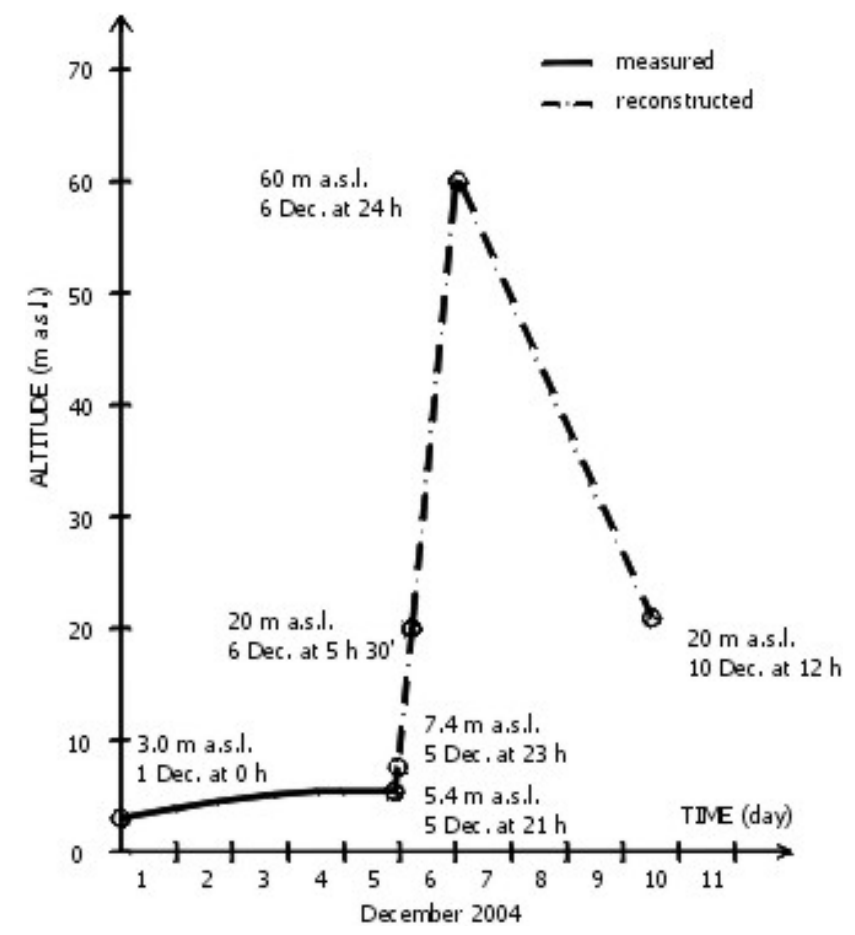

Fig. 7. Groundwater hydrograph measured in the Roman well shaft from 1 December 2005 at $0 \mathrm{~h}$ to 10 December 2005 at $12 \mathrm{~h}$.
Figure 5a shows the situation of a Roman well gallery with a length of $250 \mathrm{~m}$. Figure $5 \mathrm{~b}$ presents the cross-section of a Roman well shaft with a depth of about $80 \mathrm{~m}$. Figure $5 \mathrm{~b}$ designates the minimum and maximum measured groundwater levels in this shaft. The Roman well shaft is $2.3 \mathrm{~km}$ far from the Adriatic Sea coast, while the Dolac shaft is located about $3 \mathrm{~km}$ away. The gallery of Dolac shaft has a length of $440 \mathrm{~m}$, and its depth is $32 \mathrm{~m}$.

The average groundwater temperature is $14.7^{\circ} \mathrm{C}$, and it varies from 9.9 to $21.8^{\circ} \mathrm{C}$. The average air temperature is about $14^{\circ} \mathrm{C}$. The salinity of groundwater in both galleries varies from 8 to 700 with an average value of $187 \mathrm{mg} 1^{-1}$ of chlorides (Štambuk-Giljanović, 1997). The rise of salinity is caused by the intrusion of sea water during pumping in dry summer periods when groundwater levels are low.

Figure 6 represents a map of the studied area with the indicated positions of nine rain gauging stations and areas flooded by the karst flash flood of 6 December 2004. Near the name of each rain gauging station the quantity of precipitation measured during $24 \mathrm{~h}$ (from $7 \mathrm{~h}$ on 5 December 2004 to $7 \mathrm{~h}$ on 6 December 2005) is given. Unfortunately, not one of these nine rain gauging stations is automatic. It should be stressed that main parts of the precipitation fell during only three hours from 20 to $23 \mathrm{~h}$ on 5 December 2004.

From these data it is very probable that the centre of the rainstorm cell was over Marina bay and the village of Marina. The average annual precipitation measured at the Marina rain gauging station during the period of 1964-2004 is $905.6 \mathrm{~mm}$, 

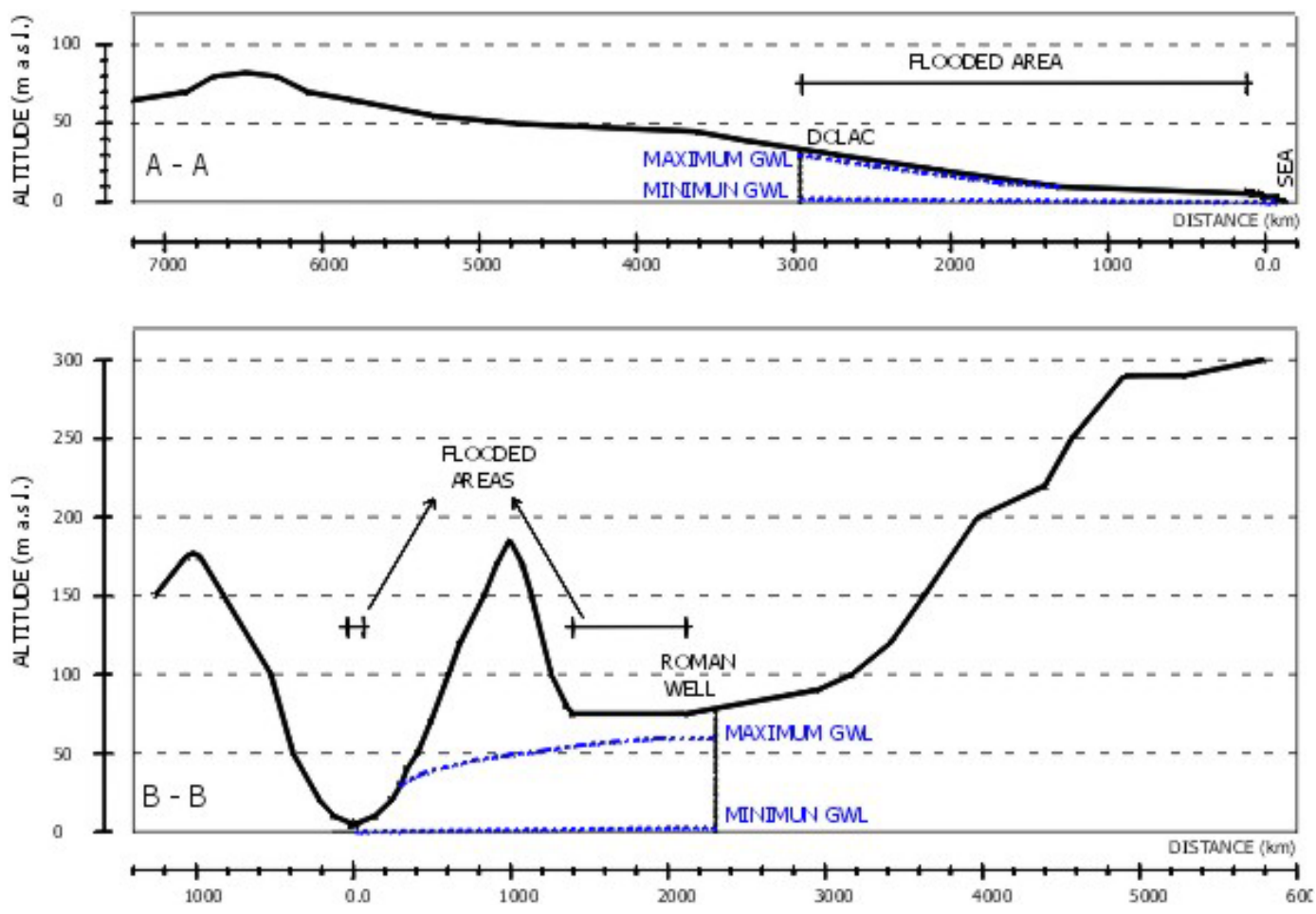

Fig. 8. Cross-sections A-A and B-B (see Fig. 4) with indicated position of two shafts, minimum and maximum groundwater levels during the analysed flash flood and flooded areas.

with a minimum of $419 \mathrm{~mm}$ in 1983 and a maximum of $1332.1 \mathrm{~mm}$ in 2004 . The average annual maximum $24 \mathrm{~h}$ precipitation measured at the same gauging station in the period of 1964-2004 is $72.6 \mathrm{~mm}$. The minimum and maximum values in the period of 1964-2003 were $28.7 \mathrm{~mm}$ in 1983 and $144 \mathrm{~mm}$ in 1993. Using Gumbel and log-normal distributions the return period of $24 \mathrm{~h}$ precipitation of $207.9 \mathrm{~mm}$ had an estimated 800 and 1000 years, respectively.

Figure 7 shows a partly measured and partly reconstructed groundwater hydrograph in the Roman well shaft. The maximum groundwater level was $60 \mathrm{~m}$ above sea level (m a.s.l.). Until 6 December 2004 the maximum measured groundwater level in the Roman well shaft was $22.5 \mathrm{~m}$ a.s.l. In the Dolac shaft the maximum groundwater level was about $30 \mathrm{~m}$ a.s.l. The intensity of rising groundwater was $2 \mathrm{~m} \mathrm{~h}^{-1}$, while the intensity of its falling was $0.5 \mathrm{~m} \mathrm{~h}^{-1}$. In Fig. 8 two crosssections designated in Fig. 4 are presented. It is seen that the groundwater level coincides with the surface of the terrain on the A-A cross-section. Hill slopes oriented in the direction of the Adriatic Sea were completely saturated by water from the height of about $30 \mathrm{~m}$ a.s.l., which made the formation of overland flow possible. Water discharging from karst underground was highly saturated with suspended sediments.

During about ten hours of the karst flash flood in Marina bay and village many intermittent karst springs appeared. Discharge from submarine springs in Marina bay was huge, but measurements were not possible. The rapid rising of groundwater caused breaches in all the Marina houses' cellars. An open water course $(0.5 \mathrm{~m}$ in height $)$ was formed through the village street. The national road was flooded by $0.2 \mathrm{~m}$ heigh water, which interrupted traffic for a few hours (see Figs. 9 and 10). It should be stressed that similar phenomena have until now never occurred in this region.

Damage caused by this karst flash flood was estimated at about 1.5 million US dollars. It is a great amount for such a small village, which has no more than 500 permanent inhabitants. Perhaps, some human activities accelerated the hazardous consequences of this karst flash flood. According to the existing data it is not possible to make any reliable conclusions about anthropogenic influences on the karst flash flood analysed.

\section{Concluding remarks}

The facts presented in this paper give definite proof that karst flash floods belong to a special kind of flash floods. As it is a relatively new concept it is necessary to develop adequate methods for their investigation and control.

It should be stressed that in different karst regions karst flash floods will manifest in different ways. Any karst system shows the extreme heterogeneity and variability of geologic, morphologic, hydrogeologic, hydrologic, hydraulic, ecological and other parameters in space and time. Such a complex 


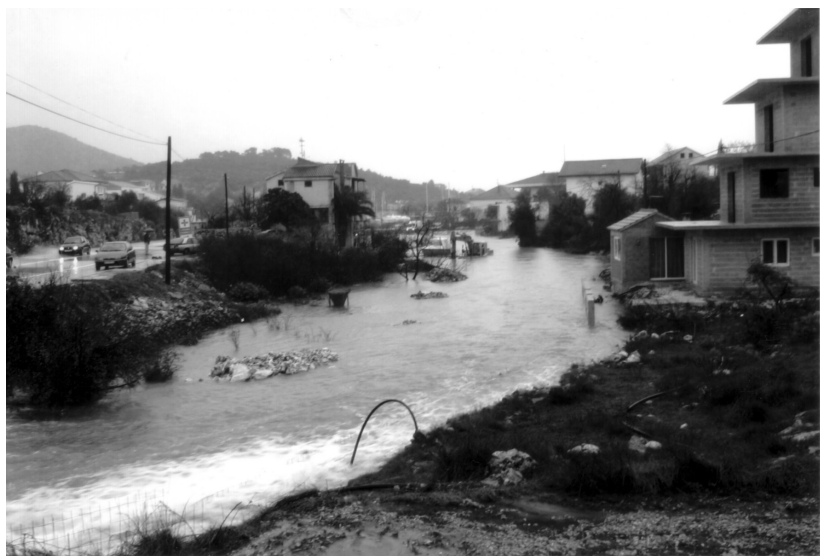

Fig. 9. Karst flash flood on 6 December 2004 in the upper part of the Marina village.

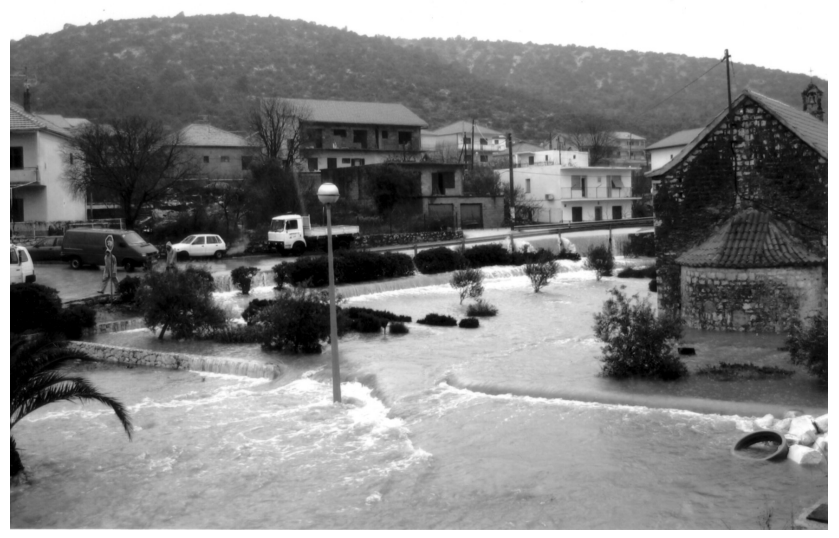

Fig. 10. Karst flash flood on 6 December 2004 in the lower part (near the Adriatic Sea coast) of the Marina village.

system needs an interdisciplinary approach. The most important characteristic of karst flash flood is the strong interaction between surface and groundwater. Due to this reason close co-operation between the investigations of hydrology and hydrogeology is necessary. The synthesis of hydrological and hydrogeological approaches could expedite progress in understanding karst flash flooding and in its control.

An especially complex and until now unsolved problem is the establishment of monitoring systems for the forecasting and warning of karst flash floods. It is necessary to increase efforts towards developing a solution in the near future. This is likely to be manifest in all aspects of hydrologic and hydrogeologic sciences, ranging from improved measurements methods, to advanced conceptual models of water flow under varying karst conditions. The sooner it starts the better prepared experts and managers will be to face the challenges of the uncertain soon-to-come future.
Acknowledgements. The authors would like to thank J. Milković and J. Goreta for providing permission to publish precipitation data and the photos of the karst flash flood in Marina and the Marina bay.

Edited by: F. Guzzetti

Reviewed by: J. Motyka and another referee

\section{References}

Archer, D.: Walls of water, Circ. British Hydrol. Soc., 44, 1-3, 1992.

Atkinson, T. C.: Diffuse flow and conduit flow in limestone terrain in Mendip Hills, Somerset (Great Britain), J. Hydrol., 35, 93100, 1977.

Bakalowicz, M.: Karst groundwater: a challenge for new resources, Hydrogeol. J., 13, 1, 2005.

Bonacci, O.: Karst hydrology with special reference to Dinaric karst, Springer Verlag, Berlin, 1987.

Bonacci, O.: Ground water behaviour in karst: example of the Ombla Spring (Croatia), J. Hydrol., 165, 113-134, 1995.

Bonacci, O.: Analyses of the maximum discharge of karst springs, Hydrogeol. J., 9, 4, 328-338, 2001.

Bonacci, O.: Hazards caused by natural and anthropogenic changes of catchment area in karst, 4, 655-661, 2004.

Bonacci, O. and Roje-Bonacci, T.: Heterogeneity of hydrological and hydrogeological parameters in karst: examples from Dinaric karst, Hydrol. Processes, 14, 14, 2423-2438, 2000.

Bonacci, O. and Živaljević, R.: Hydrological explanation of the flow in karst: example of the Crnojevića spring, J. Hydrol., 146, 405-419, 1993.

Bošković, M. and Živaljević, R.: Hidrološko osvrt na poplavu Cetinja od 18. do 20.02.1986. (Hydrologic review of the 1986 Cetinje flood), Vodoprivreda, 18, 102-103, 259-264, 1986.

Carpenter, T. M., Sperfslage, J. A., Georgakakos, K. P., Sweeney, T., and Fread, D. L.: National threshold runoff estimation utilizing GIS in support of operational flash flood warning systems, J. Hydrol., 224, 21-44, 1999.

Choquette, P. W. and Pray, L. C.: Geologic nomenclature and classification of porosity in sedimentary carbonates, Bull. Am. Assoc. Pet. Geol., 54, 207-250, 1970.

Cohen, H. and Laronne, J. B.: High rates of sediment transport by flashfloods in the Southern Judean Desert, Israel, Hydrol. Processes, Early View, 2005.

Hall, A. J.: Flash flood forecasting, Operational Hydrology Report, no. 18, World Meteorological Organisation, Geneva, 1981.

Hess, J. W. and White, W. B.: Storm response of the karstic carbonate aquifer of southcentral Kentucky, J. Hydrol., 99, 235-252, 1988.

Ford, D. C. and Ewers, R. O.: The development of limestone cave systems in the dimensions of length and depth, Can. J. Earth Sci., 15, 11, 1783-1798, 1978.

Ford, D. C. and Williams P. W.: Karst geomorphology and hydrology, Unwin Hyman, London, 1989.

Jourde, H., Roesch, A., Guinot, V., and Bailly-Compte, V.: Dynamics and contribution of karst groundwater to surface flow during Mediterranean flood, Proc. Int. Symp. Water Resour. Environ. Problems in Karst, Belgrade and Kotor, 133-138, 2005.

Kiraly, L.: Groundwater flow in fractures rocks: models and reality, 14th Mintrop Seminar über Interpretationsstrategien in Ex- 
ploration und Produktion, Ruhr Universität Bochum, 159, 1-21, 1994.

Lin, X.: Flash floods in arid and semi-arid zones, IHP-V Technical Documents in Hydrology, no. 23, 1999.

Mijatović, B.: Catastrophic flood in the polje of Cetinje in February 1986, a typical example of the environmental impact of karst, Proc. of the multidisciplinary conf. on sinkholes and the environ. impacts of karst, Orlando, Balkema, Rotterdam, 299-303, 1987.

Motyka, J.: A conceptual model of hydraulic networks in carbonate rocks, illustrated by examples from Poland, Hydrogeol. J., 6, 4, 469-482, 1998.

Roje-Bonacci, T., Miščević, P., and Turković, A.: Reconstruction of vertical shaft on part passing through clay in karst limestone, Proc. EUROROCK 2000 Symp., Aachen, 223-228, 27-31 March 2000.
Smith, K. and Ward, R.: Floods - physical processes and human impacts, John Wiley and Sons, Chichester, 1998.

Štambuk-Giljanović, N.: Rimski bunar u Gustirni kraj Trogira (Roman well in Gustirna near Trogir), Hrvatska Vodoprivreda, VI, 57, 49-54, 1997.

Trudgill, S.: Limestone geomorphology, Longman, London, 1985. Ward, R. C.: Floods: a geographical perspective, Macmillan, London, 1978.

White, W. B.: Karst hydrology: recent developments and open questions, Eng. Geology, 65, 85-105, 2002. 